\title{
ANALISIS PERLAKUAN AKUNTANSI ATAS PENDAPATAN DAN BEBAN PADA PT. SEMEN BATURAJA (PERSERO) TBK PALEMBANG
}

\author{
Oleh: Retnowenti Dwi Astari \\ (PENDAMPING PKH KEMENSOS RI)
}

wentyretno@yahoo.com

\begin{abstract}
Abstrak-Tujuan penelitian ini untuk mengetahui perbandingan pendapatan dan beban tahun 2012-2013 dan untuk mengetahui metode pencatatan dan pengakuan pendapatan dan beban. Metode penelitian yang digunakan adalah metode deskriptif. Hasil penelitian menunjukkan bahwa perbandingan pendapatan total ditahun 2013 meningkat 10\% dari tahun 2012. Sedangkan perbandingan beban total ditahun 2013 mengalami peningkatan lebih tinggi sedikit sekitar 12\% dari tahun 2012. Penjualan semen yang merupakan pendapatan utama perusahaan dan pendapatan bunga deposito yang berasal dari pendapatan keuangan dicatat menggunakan metode accrual basis. Sedangkan pendapatan denda yang berasal dari pendapatan operasional lainnya menggunakan metode cash basis. Namun, hal tersebut dinilai tidak menyalahi aturan atau prinsip akuntansi yang berlaku umum. Beban-beban yang diakui oleh perusahaan secara keseluruhan telah menggunakan metode pencatatan accrual basis. Hal tersebut telah sesuai dengan PSAK yaitu perusahaan menyusun laporan keuangan atas accrual basis.
\end{abstract}

Kata Kunci : Analisis Perlaukan Akuntansi, Pendapatan, Beban

\begin{abstract}
The research objective is to compare the income and expenses of 20122013 and to know the method of recording and recognizing income and expenses. The method used is descriptive method. The results showed that the ratio of total income in 2013 increased by 10\% from 2012. While the ratio of total expenses in 2013 increased slightly by around 12\% from 2012. Cement sales which are the company's main income and deposit interest income originating from financial income are recorded using the accrual basis method. While the income from fines from other operating income uses the cash basis method. However, this is considered not to violate generally accepted rules or accounting principles. The expenses recognized by the company as a whole have used the accrual basis recording method. This is in accordance with the PSAK, namely the company prepares financial statements for accrual basis.
\end{abstract}

Keywords: Accounting Analysis, Revenue, Expenses 


\section{PENDAHULUAN}

Setiap perusahaan pasti menginginkan laba yang optimal. Karena itu untuk mencapai laba tersebut pada kondisi saat ini sangat diperlukan kecermatan pelaksana dan perusahaan harus benar-benar dapat memenuhi keinginan konsumen atau pihak-pihak yang berhubungan dengan perusahaan. Dalam melakukan aktivitasnya setiap perusahaan harus mengeluarkan beban atau beban operasional yang akhirnya diharapkan dapat mencapai tujuan perusahaan.

Menurut Hery (2009:1) akuntansi adalah " sebuah aktivitas jasa, di mana fungsinya adalah memberikan informasi kuantitatif, terutama informasi mengenai posisi keuangan dan hasil kinerja perusahaan, yang dimaksudkan akan menjadi berguna dalam pengambilan keputusan ekonomi (dalam membuat pilihan di antara berbagai alternative yang ada). Salah satu jenis laporan keuangan adalah laporan laba rugi. Diantara beberapa laporan keuangan, laporan ini merupakan laporan yang utama untuk melaporkan kinerja dari suatu organisasi atau perusahaan. Dalam beberapa tahun belakangan ini, perhatian pada perhitungan laba rugi semakin dirasakan manfaatnya. Dengan adanya informasi mengenai pendapatan, maka dapat membandingkan antara modal yang tertanam dengan penghasilan sebagai alat untuk mengukur kinerja efisiensi perusahaan. Dalam laporan laba rugi ini tergambar jumlah pendapatan dan sumber-sumber pendapatan yang diperoleh. Kemudian, juga tergambar jumlah beban dan jenis-jenis beban yang dikeluarkan selama periode tertentu.

Pendapatan dan beban yang disajikan dalam laporan keuangan harus mencerminkan pendapatan dan beban yang benar-benar diperoleh dan dikeluarkan oleh perusahaan dalam periode tersebut. Ketidaktepatan dalam pengukuran, pengakuan, dan pengklasifikasian pendapatan dan beban, menyebabkan nilainya dalam laporan keuangan akan menjadi terlalu besar diakui (overstated) ataupun terlalu kecil diakui (understated). Sehingga hal tersebut dapat mengakibatkan terjadinya kesalahan atau penyimpangan dalam pengambilan keputusan ekonomi oleh pemakai laporan tersebut. Oleh karena itu, perusahaan menuntut pihak manajemen perlu membuat kebijakan yang mengacu pada terciptanya efisiensi dan efektifitas bisnis dalam rangka mencapai tujuan perusahaan. Diantara berbagai kebijakan perusahaan, salah satu fungsi penting adalah bagaimana perlakuan pendapatan dan beban pada perusahaan. Fungsi ini dikatakan cukup penting karena sumber laba perusahaan berasal dari pendapatan dan beban sehingga perlu diketahui pengakuan pendapatan dan beban.

Pendapatan dan beban merupakan dua elemen yang saling 
berhubungan dan berkaitan tetapi keduanya bertolak belakang. Dari sudut pandang perusahaan, pendapatan merupakan penghasilan yang diakibatkan dari kegiatan perusahaan (baik kegiatan utama maupun bukan kegiatan utama). Sedangkan beban merupakan habisnya (expirations) jasa faktor yang berkaitan langsung ataupun tidak langsung dengan kegiatan perusahaan. Pendapatan dan beban diakui dalam satu tahun tertentu yang dipengaruhi oleh pendapatan dan beban yang diakui.

PT Semen Baturaja (Persero) Tbk adalah suatu perusahaan yang bergerak di bidang industri pengelolaan semen di wilayah Sumatera Selatan. Perusahaan ini mempunyai perhatian yang cukup besar dalam mencapai tujuan utama yaitu memproduksi semen yang berkualitas, efisien, dan memasarkannya dengan mengutamakan kepuasan pelanggan dan juga harus mencapai laba yang optimal, dengan upaya bagaimana ketepatan dalam memberikan perlakuan terhadap pendapatan dan beban perusahaan yang benar. Pendapatan utama perusahaan diperoleh dari penjualan semen, sedangkan beban pada perusahaan ini timbul dari operasi perusahaan. Sebagian besar penjualan atau transaksi perusahaan dilakukan dalam bentuk tunai, sedangkan untuk penebusan semen secara kredit para distributor diwajibkan untuk menyediakan jaminan dalam bentuk bank garansi dan/atau bentuk jaminan lainnya. Menurut Harahap (2011:244) beban dibagi dalam tiga golongan, yaitu: 1).Biaya yang dihubungkan dengan penghasilan pada periode itu; 2) Biaya yang dihubungkan dengan periode tertentu yang tidak dikaitkan dengan penghasilan; 3). Biaya yang karena alasan praktis tidak dapat dikaitkan dengan periode manapun.

Pada PT. Semen Baturaja (Persero) Tbk Palembang pendapatan atas penjualan barang diakui pada saat resiko dan hak atas pemilikan barang secara signifikan telah berpindah kepada pembeli. Sedangkan beban diakui pada saat terjadinya atau sesuai dengan masa manfaatnya. Selain pendapatan atas penjualan barang PT. Semen Baturaja (Persero) Tbk Palembang memiliki pendapatan keuangan dan pendapatan operasi lainnya. Sebagai contoh pendapatan keuangan yaitu pendapatan bunga. Pendapatan bunga di masa datang didasarkan pada nilai tercatat yang telah dikurangi dan diakui berdasarkan suku bunga yang digunakan untuk mendiskontokan arus kas masa datang untuk tujuan pengukuran kerugian penurunan nilai. Beban perusahaan juga memiliki beberapa klasifikasi selain beban pokok penjualan yaitu beban penjualan, beban umum dan administrasi, beban operasi lainnya dan beban keuangan. Sebagai contoh beban umum dan 
administrasi yaitu beban pajak kini dan sewa. Beban pajak kini ditentukan berdasarkan laba kena pajak dalam tahun yang bersangkutan yang dihitung berdasarkan tarif pajak yang berlaku. Kecuali untuk usaha yang pendapatannya dikenakan pajak final, semua perbedaan temporer antara jumlah tercatat aset dan liabilitas dengan dasar pajaknya diakui sebagai pajak tangguhan dengan metode liabilitas (liability method). Untuk sewa operasi, Perseroan mengakui pembayaran sewa sebagai beban dengan dasar garis lurus selama masa sewa.

Menurut Santoso (2007:90) pendapatan merupakan arus masuk atau penambahan aktiva atau penyelesaian suatu kewajiban atau kombinasi dari keduanya yang berasal dari penyerahan atau produksi barang atau aktivitasaktivitas lainnya yang merupakan operasi utama atau operasi inti yang berkelanjutan. Dalam Standar Akuntansi Keuangan dinyatakan perusahaan harus menyusun laporan keuangan atas dasar akrual. Suatu pendapatan diakui bila besar kemungkinan manfaat ekonomi sehubungan dengan transaksi tersebut akan mengalir kepada perusahaan. Oleh karena itu, apabila perlakuan pendapatan dan beban perusahaan tidak sesuai dengan Standar Akuntansi Keuangan yang berlaku umum maka akan berpengaruh terhadap laporan keuangan perusahaan khususnya laporan laba rugi.

Berdasarkan uraian yang melatarbelakangi permasalahan di atas, peneliti tertarik untuk melakukan penelitian mengenai pendapatan dan beban dengan judul "Analisis Perlakuan Akuntansi atas Pendapatan dan Beban pada PT. Semen Baturaja (Persero) Tbk Palembang" pertanyaan dalam penelitian ini adalah "Bagaimanakah perbandingan pendapatan dan beban periode 2012-2013 pada PT. Semen Baturaja (Persero) Tbk Palembang? "Bagaimanakah metode pencatatan dan pengakuan pendapatan dan beban yang digunakan pada PT. Semen Baturaja (Persero) Tbk Palembang? Penelitian ini bertujuan: Untuk mengetahui perbandingan pendapatan dan beban periode 20122013 pada PT. Semen Baturaja (Persero) Tbk Palembang. Untuk mengetahui metode pencatatan dan pengakuan pendapatan dan beban pada PT. Semen Baturaja (Persero) Tbk Palembang.

\section{METODE PENELITIAN}

Metode penelitian yang digunakan peneliti adalah metode deskriptif.

Metode deskriptif adalah suatu metode dalam meneliti status sekelompok manusia, suatu objek, suatu set kondisi, suatu sistem pemikiran, ataupun suatu keadaan peristiwa pada masa sekarang. Tujuan untuk penelitian ini adalah 
untuk membuat deskripsi, gambaran atau lukisan secara sistematis faktual dan akurat mengenai fakta-fakta, sifat-sifat serta hubungan antarfenomena yang diselidiki (Nazir, 2013:43).

\section{Teknik Pengumpulan Data}

Teknik yang digunakan untuk mengumpulkan data sangat membantu dalam tercapainya tujuan penelitian. Sesuai dengan data yang akan dikumpulkan pada penelitian ini maka penelitian memakai pengumpulan data berupa:

\section{Dokumentasi}

Teknik dokumentasi untuk memperoleh data dan informasi yang berkaitan dengan perlakuan akuntansi atas pendapatan dan beban pada PT. Semen Baturaja (Persero) Tbk Palembang yaitu data : Keadaan umum perusahaan termasuk struktur organisasi, Laporan Laba/Rugi tahun 2012 dan 2013, Komponen pendapatan dan beban tahun 2012 dan 2013, Transaksi pendapatan dan beban

\section{Wawancara (interview)}

Teknik pengumpulan data yang dikumpulkan berasal dari opini subjek yang diperoleh dari hasil wawancara yaitu dengan jalan tanya jawab langsung kepada pimpinan perusahaan atau yang ditunjuk untuk itu guna mengetahui jenis-jenis pendapatan dan beban, waktu pengakuan pendapatan dan beban, kriteria pengakuan pendapatan dan beban, kendala dalam pencatatan pengakuan pendapatan dan beban yang digunakan dalam memberi perlakuan akuntansi atas pendapatan dan beban di PT. Semen Baturaja (Persero) Tbk Palembang.

\section{Teknik Analisis Data}

Teknik analisis yang digunakan dalam penelitian ini adalah sebagai berikut:

\section{Analisis Pendapatan}

Perbandingan pendapatan antar periode dengan rumus sebagai berikut:

$$
P=\frac{R n}{R o} \times 100 \%
$$

Keterangan:

$\mathrm{P}=$ Perbandingan antar periode. $\mathrm{Rn}=$ Revenue (pendapatan) periode sekaran.

$\mathrm{Ro}=$ Revenue (pendapatan) periode sebelum $100 \%=$ Persentase

a. Perlakuan akuntansi atas pendapatan:

1. Jenis-jenis pendapatan

2. Prosedur pencatatan pendapatan

3. Perlakuan akuntansi dalam pengakuan pendapatan dengan menggunakan jurnal (metode cash basis dan accrual basis).

\section{Analisis Beban}

a. Perbandingan beban antar periode dengan rumus sebagai berikut:

$$
P=\frac{E n}{E_{0}} \times 100 \%
$$

Keterangan:

$\mathrm{P}=$ Perbandingan antar periode 


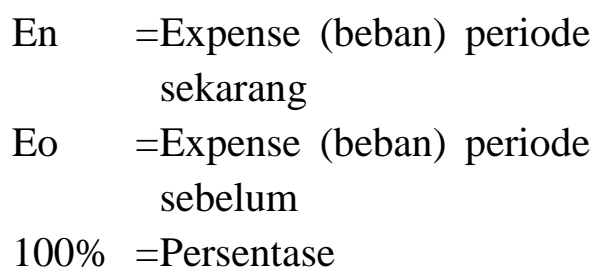

\section{Perlakuan akuntansi atas beban:}

1. Jenis-jenis beban

2. Prosedur pencatatan beban

3. Perlakuan akuntansi dalam pengakuan beban dengan menggunakan jurnal (metode cash basis dan accrual basis).

\section{HASIL PENELITIAN \\ Deskripsi Tempat Penelitian}

PT Semen Baturaja (Persero)

Tbk didirikan 14 Nopember 1974 oleh PT Semen Gresik dengan saham 45\% dan PT Semen Padang 55\%. Pada tanggal 9 Nopember 1979 status Perusahaan berubah dari Penanaman Modal Dalam Negeri (PMDN) menjadi Persero dengan komposisi saham Pemerintah Republik Indonesia 88\%, PT Semen Padang 7\% dan PT Semen Gresik 5\%. Sejak tahun 1991 diambil alih secara keseluruhan oleh Pemerintah Republik Indonesia. Pada tanggal 14 Maret 2013 PT Semen Baturaja (Persero) berubah status menjadi Perseroan terbuka yang disebut PT Semen Baturaja (Persero) Tbk berdasarkan :

1. Akte No.21 tanggal 14 Maret 2013 yang dibuat dihadapan Fathiah Helmi, SH. Notaris/PPAT di Jakarta dan telah mendapatkan pengesahan dari Kementerian
Hukum dan HAM Republik Indonesia No.AHU1374.AH.01.02, 2013, tanggal 18 Maret 2013 dan No 55 tanggal 24 Januari 2014, yang disahkan oleh Menteri Hukum dan HAM dengan surat keputusan Nomor AHU-AH 01.10-03080 Tahun 2014, tanggal 29 Januari 2014.

2. Peraturan Pemerintah No.39 tahun 2013 tanggal 21 Mei 2013 tentang Perubahan Struktur Kepemilikan Saham Negara melalui Penerbitan dan Penjualan Saham Baru pada Perusahaan Perseroan (Persero) PT Semen Baturaja.

PT Semen Baturaja (Persero) Tbk memproduksi dua tipe semen :

1) Ordinary Portland Cement (OPC) Tipe I Indonesian Standard : SNI 15-2049-2004, American Standard : ASTM C 150-04a, European Standard : EN 1971:2000. Semen Portland Tipe I merupakan jenis semen yang cocok untuk berbagai macam aplikasi beton dimana syaratsyarat khusus tidak diperlukan.

2) Portland Composite Cement (PCC) Idonesian Standard : SNI 15-7064-2004, European Standard : EN 197-1:2000 (42.5 N\&42.5 R). PCC digunakan untuk bangunan-bangunan pada umumnya, sama dengan penggunaan Semen Portland Tipe I dengan kuat tekan yang sama. PCC mempunyai panas hidrasi yang lebih rendah selama proses 
pendinginan dibandingkan dengan Semen Portland Tipe I, sehingga pengerjaannya akan lebih mudah dan menghasilkan permukaan beton/plester yang lebih rapat dan lebih halus.

Pusat Produksi terletak di Baturaja yaitu produksi Terak. Sedangkan proses penggilingan dan pengantongan semen dilaksanakan di Pabrik Baturaja, Pabrik Palembang dan Pabrik Panjang yang selanjutnya siap untuk didistribusikan ke daerahdaerah pemasaran. Untuk penyempurnaan peralatan yang sudah ada dalam rangka pencapaian kapasitas terpasang, yaitu sebesar 500.000 ton semen per tahun, sekaligus persiapan untuk meningkatkan kapasitas terpasang, PT Semen Baturaja (Persero) Tbk melaksanakan Proyek Optimalisasi I (OPT I). Proyek ini dimulai tahun 1992 dan selesai tahun 1994 dengan kapasitas terpasang meningkat menjadi 550.000 ton semen per tahun.

Sebagai tindak lanjut proyek OPT I, pada tahun 1996 Perseroan melaksanakan Proyek Optimalisasi II (OPT II), untuk meningkatkan kapasitas menjadi sebesar 1.250.000 ton semen per tahun. Proyek OPT II selesai tahun 2001 dan telah berproduksi sampai sekarang. Pada tanggal 20 Juni 2004 PT Semen Baturaja (Persero) Tbk menerbitkan Obligasi I sebesar Rp.200 milyar. Emisi obligasi ini merupakan program lanjutan Restrukturisasi keuangan dalam rangka meningkatkan profitabilitas sekaligus likuiditas Perseroan. Perseroan telah melakukan pelunasan atas pinjaman Obligasi I pada bulan Juni 2010.

Tahun 2011, Perseroan melakukan Pembangunan proyek Cement Mill and Packer dengan kapasitas 750.000 ton semen per tahun dan telah beroperasi komersil pada bulan Juli 2013, sehingga kapasitas Perseroan menjadi 2.000.000 ton semen per tahun. Tanggal 28 Juni 2013, PT Semen Baturaja (Persero) Tbk melaksanakan Initial Public Offering (IPO) dengan melepas $23,76 \%$ atau 2.337.678.500 saham ke publik yang akan digunakan untuk membiayai pembangunan pabrik Baturaja II dengan kapasitas 1,85 juta ton semen per tahun.

Dari sisi pemasaran, PT Semen Baturaja (Persero) Tbk memiliki daerah pasar utama yaitu Sumatera Selatan dan Lampung yang merupakan wilayah di Indonesia yang menikmati petumbuhan ekonomi yang cukup baik dan stabil. Hal ini memberi peluang bagi Semen Baturaja untuk meningkatkan penjualan dan mencapai kapasitas terpasang. Dalam menyalurkan produknya Perseroan menggunakan distributor dengan jaringan yang tersebar diseluruh wilayah Sumatera Selatan, Lampung, Jambi dan Bengkulu. Sebagian besar penjualan Perseroan dilakukan dalam bentuk tunai, sedangkan untuk penebusan 
semen secara kredit para distributor diwajibkan untuk menyediakan jaminan dalam bentuk bank garansi dan/atau bentuk jaminan lainnya.

Keberadaan PT Semen Baturaja (Persero) Tbk banyak memberikan manfaat baik langsung maupun tidak langsung, berupa pajak dan retribusi kepada Pemerintah Pusat dan Daerah, dividen kepada Pemegang Saham, kesempatan kerja, maupun dalam bentuk Kemitraan dan Bina Lingkungan bagi masyarakat sekitar pabrik.

\section{Visi PT. Semen Baturaja (Persero)} Tbk

PT Semen Baturaja (Persero) Tbk, melakukan review terhadap Visi, Misi Perseroan yang disahkan pada tanggal 20 Januari 2012 dalam Rapat Umum Pemegang Saham (RUPS) Rencana Jangka Panjang Perusahaan (RJPP) tahun 2012-2016. Visi PT Semen Baturaja (Persero) Tbk yaitu menjadi produsen semen yang efisien, mempunyai daya saing dan tumbuh.

\section{Misi PT. Semen Baturaja (Persero) Tbk}

Misi Perseroan yang disahkan pada tanggal 20 Januari 2012 dalam Rapat Umum Pemegang Saham (RUPS) Rencana Jangka Panjang Perusahaan (RJPP) tahun 2012-2016 adalah sebagai berikut:

$\begin{array}{lrr}\text { 1) Memproduksi } & \text { semen } & \text { yang } \\ \text { berkualitas, } & \text { efisien } & \text { dan } \\ \text { memasarkannya } & & \text { dengan }\end{array}$

mengutamakan

kepuasan

pelanggan serta berwawasan lingkungan.

2) Membangun Sumber Daya Manusia yang profesional.

3) Memaksimalkan nilai tambah Perusahaan bagi Stakeholder.

\section{Deskripsi Data}

Jenis Pendapatan dan Beban PT. Semen Baturaja (Persero) Tbk Palembang.

\section{Jenis Pendapatan}

Pendapatan PT. Semen

Baturaja (Persero) Tbk terbagi menjadi tiga sumber pendapatan, yaitu:

1. Pendapatan dari kegiatan utama perusahaan yang berasal dari penjualan semen.

2 Pendapatan operasional lainnya yang meliputi pendapatan klaim, pendapatan denda, pendapatan lainnya dan laba (rugi) selisih kurs transaksi

3. Pendapatan keuangan yang terdiri dari pendapatan bunga deposito, pendapatan jasa giro, pendapatan bunga tabungan, dan laba (rugi) selisih kurs transaksi. (Sumber data: Wawancara pada tanggal 14 Agustus 2014)

\section{Jenis Beban}

Beban pada PT. Semen Baturaja (Persero) Tbk terbagi menjadi lima jenis, yaitu beban pokok penjualan, beban penjualan, beban umum dan administrasi, beban keuangan dan beban pajak 
penghasilan. Berikut ini diuraikan unsur-unsur tersebut secara rinci.

1) Beban pokok penjualan (cost of sales) yang terdiri dari:

a. Bahan baku dan penolong (Raw material and supplies)

b. Listrik (Electricity)

c. Pengangkutan (Transportation)

d. Biaya tenaga kerja ( Labor costs)

f. Penyusutan (Depreciation)

g. Pemeliharaan (Maintenance)

h. Biaya pabrikasi lainnya (Other manufacture expenses)

2) Beban pokok produksi (Cost of goods manufacture), terdiri dari : Persediaan awal (Beginning balance), Pembelian (Purchase), Persediaan akhir ( Ending balance.

3) Beban Penjualan (Selling Expenses) yang terdiri dari:

a. Gaji, upah dan tunjangan ( Salaries, wages and allowances)

b. Promosi (Promotion)

c. Perjalanan dinas (Business trip)

d. Penyusutan (Depreciation)

e. Telekomunikasi (Telecommunication)

4) Beban pemeliharaan Lainnya (Maintenance)

5) (General And Administrative Expense) yang terdiri dari:

a. Gaji, upah dan tunjangan (Salaries, wages and allowance)

b. Perjalanan dinas (Bussiness trip) c. Beban

pemeliharaan

(Maintenance)

d. Sewa (Rent)

e. Diklat dan detasering (Training and "detasering")

f. Jasa profesional (Professional Fee)

g. Sumbangan (Donation)

h. Telekomunikasi (Telecomunication)

i. Listrik dan Air (Electricity and water)

j. Penyusutan (Depreciation)

k. Rapat dinas (Meeting)

1. Alat tulis kantor (Stasioneries)

m. Keamanan (Security)

n. Asuransi (Insurance)

o. Pembinaan jasmani dan rohani (Mental and physical development)

p. Pajak (Taxes)

q. Penelitian dan Pengembangan (Research and development)

r. Pengangkutan (Transportation)

s. Lainnya

6) Beban Keuangan (Financial Expense) yaitu Beban bunga Kredit Modal Kerja

7) Beban pajak penghasilan (Income Tax Expenses) yang terdiri dari:

a.Pajak kini (Current tax)

b.Pajak tangguhan (Deferred tax) (Sumber data: Wawancara pada tanggal 14 Agustus 2014)

PEMBAHASAN

Perbandingan Pendapatan dan Beban 
Pendapatan total tahun 2013 lebih tinggi $10 \%$ dibanding tahun 2012, namun kenaikan pendapatan ini diikuti oleh kenaikan beban sebesar $12 \%$. Dilihat dari pendapatan usaha yang merupakan pendapatan dari kegiatan utama yaitu penjualan semen. Kenaikan jumlah pendapatan tahun 2013 sebesar Rp.81.567.023,-diikuti dengan kenaikan jumlah beban pokok penjualan yang lebih besar yaitu Rp.113.338.506,-. Bila dibandingkan jumlah kenaikan pendapatan dengan kenaikan jumlah beban pokok penjualan, ternyata setiap Rp 1,00 penjualan, beban pokok penjualan sebesar $\mathrm{Rp} 1,39$ sehingga beban pokok penjualan lebih tinggi dibanding penjualan. Hal ini berarti untuk menghasilkan kenaikan penjualan sebesar Rp 1,00 diperlukan atau dikeluarkan biaya sebesar RP.1,39.

Dilihat dari persentasenya ternyata kenaikan pendapatan usaha tahun 2013 sebesar 6\%, diiringi pula kenaikan beban penjualan sebesar $16 \%$. Akibat dari kenaikan beban pokok penjualan dari kenaikan pendapatan usaha, maka berdampak pada profit margin tahun 2013 sebesar:

(531.539.084/1.343.899.007) x 100\% $= \pm 39,55 \%$, lebih kecil dari profit margin tahun 2012 sebesar: $(563.310 .567 / 1.262 .331 .984) \times 100 \%$ $= \pm 44,62 \%$.

\section{Perlakuan Akuntansi Atas}

Kebijakan akuntansi yang diterapkan PT. Semen Baturaja (Persero) Tbk dalam menyajikan jenis-jenis pendapatan di dalam laporan laba rugi telah sesuai dan memenuhi batasan serta kriteriakriteria yang ditetapkan dalam Standar Akuntansi Keuangan. Hal ini dikarenakan PT. Semen Baturaja (Persero) Tbk telah menyajikan pendapatan ke dalam dua bagian, yaitu pendapatan utama (pendapatan dari hasil utama kegiatan operasional perusahaan), pendapatan operasional lainnya dan pendapatan keuangan (pendapatan yang bukan dari hasil kegiatan utama perusahaan).

Menurut Yadiati (2010:65) pengukuran merupakan pemetaan (mapping) suatu angka kepada objek atau peristiwa menurut aturan tertentu. Akuntansi merupakan pengukuran dari peristiwa dan transaksi-transaksi bisnis dari satu entitas yang telah diidentifikasi dengan angka-angka dan dengan atribut yang relevan. Pencatatan cash basis ini terjadi apabila pelanggan terlambat membayar, dan keterlambatan itu terjadi mulai bulan berikutnya, sehingga penerimaan per kas atas denda tersebut memang wajar jika diakui berdasarkan cash basis; dan pendapatan denda nilainya tidak terlalu signifikan atas total pendapatan perusahaan, namun bukan bermaksud untuk tidak mengindahkan hal ini. Dengan diterapkannya jurnal pengakuan tersebut, pendapatan telah diakui 
secara accrual basis dan cash basis. Dengan demikian, dapat disimpulkan bahwa perlakuan pendapatan yang diterapkan oleh PT. Semen Baturaja (Persero) Tbk telah dilakukan secara wajar dan sesuai dengan prinsip akuntansi yang berlaku umum yaitu sesuai Standar Akuntansi Keuangan (SAK).

\section{Perlakuan Akuntansi Atas Beban}

PT. Semen Baturaja (Persero) Tbk Palembang menerapkan penyajian beban di dalam laporan laba rugi yang terjadi selama satu periode akuntansi di dalam dua pos utama, yaitu beban usaha atau operasional perusahaan yang berasal dari beban pokok penjualan, beban penjualan, beban umum dan administrasi; dan beban di luar usaha yang berasal dari beban keuangan dan beban pajak penghasilan. Jadi, dalam menyajikan beban tersebut, PT. Semen Baturaja (Persero) Tbk Palembang telah sesuai dengan ketentuan yang berlaku, di mana berdasarkan teori yang ada bahwa beban disajikan ke dalam dua bagian besar, yaitu beban dari aktivitas operasional dan beban yang berasal dari aktivitas di luar operasional perusahaan. Dengan demikian, dapat dilihat dan dapat dipisahkan dengan jelas antara beban yang berasal dari operasi utama dan beban yang berasal di luar operasi utama perusahaan.

Dalam menentukan beban yang terjadi selama satu periode, perusahaan mengakui beban yang terjadi dalam kegiatan operasionalnya selama periode tertentu, yaitu selama jangka waktu satu periode akuntansi. Hal ini diperkuat dengan penjurnalan yang dilakukan perusahaan seperti pada bab IV bagian 4.1.3.2.2. huruf B, dari beberapa jurnal tersebut, dapat diketahui bahwa perusahaan telah menerapkan pengakuan beban yang sesuai dengan kriteria dan perhitungan tiap transaksinya. Dengan diterapkannya jurnal pengakuan tersebut, maka beban telah diakui secara accrual basis, bukan cash basis dan telah sesuai dalam hal pencatatan beban. Dengan demikian, dapat disimpulkan bahwa pengakuan beban yang diterapkan oleh PT. Semen Baturaja (Persero) Tbk telah memadai dan sesuai dengan prinsip akuntansi yang berlaku umum yaitu Standar Akuntansi Keuangan (SAK).

\section{KESIMPULAN}

Berdasarkan hasil penelitian dan pembahasan pada Bab IV mengenai analisis perlakuan akuntansi atas pendapatan dan beban di PT. Semen Baturaja (Persero) Tbk Palembang, maka dapat disimpulkan bahwa: Pendapatan usaha kegiatan utama perusahaan tahun 2013 hanya meningkat relatif kecil yaitu $6 \%$ dibanding tahun 2012, sedangkan beban pokok penjualan thun 2013 meningkat lebih besar yaitu 16\% dibanding tahun 2012. Pendapatan 
total tahun 2013 meningkat lebih tinggi sebesar $10 \%$ dibanding pendapatan total tahun 2012, namun diikuti pula peningkatan beban total tahun 2013 sebesar 12\% dibanding tahun 2012. Peningkatan beban lebih tinggi dari peningkatan pendapatan uasaha kegiatan utama, telah mengakibatkan profit margin tahun 2013 sebesar 39,55\% lebih rendah dibanding tahun 2012 yaitu sebesar $44,62 \%$.

Jenis pendapatan PT. Semen Baturaja (Persero) Tbk dalam pengklasifikasian atau penyajian laporan laba rugi terdiri dari tiga sumber yaitu a) pendapatan utama, b) pendapatan operasional lainnya, dan pendapatan keuangan. Sedangkan beban terdiri dari lima sumber pengeluaran yaitu a) beban pokok penjualan, b) beban penjualan, c) beban administrasi dan umum, d) beban operasional lainnya dan e) beban pajak penghasilan. Penyajian tersebut telah sesuai dengan Pernyataan Standar Akuntansi Keuangan yaitu menyajikan seluruh pos pendapatan dan beban yang diakui dalam satu periode dalam bentuk laporan laba rugi komprehensif.

\section{DAFTAR PUSTAKA}

Harahap, Sopyan Syafri. 2008.Teori Akuntansi. Jakarta: PT. Raja Grafindo Persada

Hery. 2009. Akuntansi Keuangan Menengah 1. Jakarta: Bumi Aksara Ikatan Akuntan Indonesia. 2009. Standar
Akuntansi Keuangan. Jakarta: Salemba Empat.

Nazir, Muh. 2009. Metode Penelitian. Jakarta: Erlangga

Santoso, Iman. 2007. Akuntansi Keuangan Menengah (Intermediate Accounting). Bandung: PT. Refika Aditama Yadiati, Winwin. 2010. Teori Akuntansi Suatu Pengantar.Jakarta: Kencana 